\title{
A review of the microgastropod genus Systenostoma Bavay \& Dautzenberg, 1908 and a new subterranean species from China (Gastropoda, Pulmonata, Hypselostomatidae)
}

\author{
Adrienne Jochum ${ }^{1, \dagger}$, Rajko Slapnik ${ }^{2, \ddagger}$, Marian Kampschulte, $3, \S$, \\ Gunhild Martels ${ }^{3,1}$, Markus Heneka ${ }^{4, \pi}$, Barna Páll-Gergely,\#
}

I Department of Community Ecology, Institute of Ecology and Evolution, Baltzerstrasse 6, University of Bern, CH-3012 Bern, Switzerland 2 Drnovškova pot 2, Mekinje, 1240 Kamnik, Slovenia 3 Universitätsklinikum Gießen und Marburg GmbH-Standort Gießen, Zentrum für Radiology, Abteilung für Radiologie, Klinik-Str. 33, 35385 Gießen, Germany 4 RJL Micro \& Analytic GmbH, Im Entenfang 11, 76689 Karlsdorf-Neuthard, Germany 5 Department of Biology, Shinshu University, Matsumoto 390-8621, Japan

† http://zoobank.org/0A945916-C4FE-424A-8D0F-6FABA2BF289B

† http://zoobank.org/09E86269-966B-49E6-AB92-31B66968DCOD

§ http://zoobank.org/9E955DE5-576F-4793-BADA-OF92EF4C3015

| http://zoobank.org/A28CDA62-B880-4002-A1C9-C7FF605DBB32

I http://zoobank.org/1389FABA-1FFF-460A-88EC-E912DA6EFF78

\# http://zoobank.org/31E196E9-5A51-4295-9A36-D5DA689502B7

Corresponding author: Barna Páll-Gergely (pallgergely2@gmail.com)

Academic editor: M. Haase | Received 12 March 2014 | Accepted 7 May 2014 | Published 20 May 2014

http://zoobank.org/E4C040C1-9396-40F1-8C12-D9518F59F668

Citation: Jochum A, Slapnik R, Kampschulte M, Martels G, Heneka M, Páll-Gergely B (2014) A review of the microgastropod genus Systenostoma Bavay \& Dautzenberg, 1908 and a new subterranean species from China (Gastropoda, Pulmonata, Hypselostomatidae). ZooKeys 410: 23-40. doi: 10.3897/zookeys.410.7488

\begin{abstract}
A review of the microgastropod genus Systenostoma is provided. Thai and Malaysian species are transferred to a new genus, Angustopila (type species: Systenostoma tamlod Panha \& Burch 1999). A new subterranean Angustopila species is described here. Conchologically, the new species is most similar to the cave-dwelling, Thai A. tamlod (Panha \& Burch, 1999). One Thai species (Systenostoma edentata) is transferred to the genus Hypselostoma. Vietnamese members remain in the genus Tonkinospira (nomen novum) for Systenostoma Bavay \& Dautzenberg 1908 (non Systenostoma Marsson 1887). A comprehensive map of former Systenostoma species is presented. SEM and NanoCT images, including a video of $A$. huoyani $\mathbf{s p .} \mathbf{n}$. internal shell morphology, pro-
\end{abstract}

Copyright Adrienne Jochum et al. This is an open access article distributed under the terms of the Creative Commons Attribution License (CC BY 4.0), which permits unrestricted use, distribution, and reproduction in any medium, provided the original author and source are credited. 
vide novel perspectives of the shells of Angustopila and of the scarcely known Vietnamese Tonkinospira species. The biology of these snails is not yet known but collection localities suggest a troglophilic ecology.

\section{Keywords}

Taxonomy, subterranean snail, Pupillidae, Vertiginidae, conservation, cave-dwelling species

\section{Introduction}

Microgastropods are less than $5 \mathrm{~mm}$ in size and represent the majority of worldwide tropical land snail diversity. They are restricted to specific microhabitats such as limestone rock surfaces or caves, have limited active dispersal ability and thus, frequently demonstrate high local endemism. Due to their small size and high degree of endemicity, our knowledge of the taxonomy and ecology of microgastropod taxa such as the hypselstomatid genus Systenostoma is limited. Consequently, very little is known about tiny species and thus, the complex systematics of most tropical microgastropod groups is based on conchological characters only.

The microgastropod genus Systenostoma was established as a subgenus of Helix by Bavay and Dautzenberg (1908) for two Vietnamese species described in the same paper, namely Helix (Systenostoma) pulverea and H. (S.) pauperrima. The diagnosis of Systenostoma however, was given in another paper published a year later (Bavay and Dautzenberg 1909). The third Vietnamese species was described as Systenostoma defixa Bavay \& Dautzenberg (1912). After these descriptions, Systenostoma remained in the dark for almost four decades. Jaeckel (1950) described Angustopila depressa from the debris of an unknown Tonkinese (Northern Vietnam) tropical river. Therefore, knowledge of the distribution and ecology of this species is lacking. More recently, four species of Systenostoma were described from Thailand, namely S. concava and S. elevata by Thompson and Upatham (1997) and S. edentata and S. tamlod by Panha and Burch (1999). The genus was also reported from Malaysia, but the systematic position of the Malaysian samples is not yet clarified. Although Benthem-Jutting's (1949) figure of "Hypselostoma laidlawi" (Fig. 9) and her Paraboysidia neglecta (Benthem-Jutting, 1961) are similar and represent the same species according to her explanation, these illustrations likely show two different species (see Panha and Burch 1999).

The classification of Systenostoma is problematic. Together with the suspected, closely related genera (e.g. Acinolaemus Thompson \& Upatham, 1997, Anauchen Pilsbry, 1917, Boysidia Ancey, 1881, Hypselostoma Benson, 1856, Krobylos Panha \& Burch, 1999, Gyliotrachela Tomlin, 1930), Systenostoma is sometimes classified within Pupillidae (e. g. Panha and Burch 1999) or Vertiginidae (e.g. Thompson and Upatham 1997). These related genera are classified within Hypselostomatidae by Schileyko (1998). After examining the type species of the genus, Schileyko (1998) concluded that unlike these other genera, Systenostoma probably does not belong to Hypselostomatidae, but rather, likely belongs to Helicodiscidae because of the characteristic spiral sculpture. Later, Schileyko postulated that the genus is possibly related to Aulacospira as considered by 
Pilsbry (1917) or to Pupisoma (Valloniidae) (Schileyko 2011). Before the description of the Thai species, previous diagnoses (Bavay and Dautzenberg 1909, Pilsbry 1917, Zilch 1959) described the genus as a taxon lacking apertural dentition. Thompson and Upatham (1997) claimed that Systenostoma species bear no teeth and that a low fold may be present on the parietal wall. Moreover, they described the sculpture as "dense mesh of very fine granular reticulation superimposed upon which are fine spiral threads. Spiral sculpture may be present or absent on the protoconch". Thompson and Upatham (1997) hypothesized a close relationship between Systenostoma and Acinolaemus based on the likely, homologous parietal lamella and similar protoconch sculpture.

All Systenostoma have a relatively simple shell compared to the other members

of the family Hypselostomatidae, whose shells usually have oddly coiled shapes and multiple apertural denticles. Still, Systenostoma species show a high diversity in general shell shape, aperture shape and dentition and shell sculpture. Systenostoma seems to represent a "collection bin" taxon for species possessing few or no denticles. The reduction of the apertural teeth however, could have evolved independently in different evolutionary lineages. In this case, congeners may well have been classified/lumped within one genus but systematically belong to at least three genera. In the following, we describe a new, subterranean species from China, present an overview of all former Systenostoma species, describe a new genus for Thai, Malaysian and the new Chinese species, transfer S. edentata to the genus Hypselostoma and assign a new name (Tonkinospira) to the Vietnamese species because the name Systenostoma (non Systenostoma Marsson 1887) is preoccupied. We present SEM and Nano-CT images of shells of the new species and the scarcely known Vietnamese members of the genus.

\section{Material and methods}

\section{Abbreviations}
RBINS Royal Belgian Institute of Natural Sciences (Brussels, Belgium)
SMF Senckenberg Forschungsinstitut und Naturmuseum (Frankfurt am Main, Germany)

MCSMNH Malacological collection of the Slovenian Museum of Natural History (Ljubljana, Slovenia)

SMNS Staatliches Museum für Naturkunde Stuttgart (Stuttgart, Germany)

\section{Image acquisition}

SEM: One paratype of Angustopila huoyani sp. n. was mounted on an aluminium stub, gold-palladium sputtered using the Edwards Kniese Sputter Coater S150B (Marburg, Germany) and subsequently scanned on the CamScan CS 24 scanning electron microscope (Dortmund, Germany). Specimens of Tonkinospira nom. n. were non-coated 
and imaged with the Zeiss EVO LS15 scanning electron microscope (Jena, Germany) using the Variable Pressure (VP) mode.

Micro-CT: Tonkinospira nom. n. species were imaged using a nano-computed tomography system (nano-CT), manufactured and developed by Bruker-Micro-CT/SkyScan (SkyScan 2011, Kontich, Belgium) at the Department of Experimental Radiology, Justus-Liebig University Biomedical Research Center Seltersberg (BFS), Giessen, Germany. The scanner is based on a nanofocus tube generating X-rays in cone-beam geometry. Briefly, the system contains an open pumped type X-ray source, a LaB6 cathode and a transmission anode consisting of a tungsten-coated beryllium window. Enhanced edge sharpness is gained by a high-focussed X-ray spot of $300 \mathrm{~nm}$ side length (see Langheinrich et al. (2010) for more details). Specimens of Tonkinospira nom. n. were mounted on a computer-controlled stage. They were then scanned $180^{\circ}$ around their vertical axis in rotation steps of $0.2^{\circ}$ at $80 \mathrm{kV}$ tube voltage and $120 \mu \mathrm{A}$ tube current. Reconstruction of cross sectional images was performed using a modified Feldkamp cone-beam reconstruction algorithm. Image resolution of the cross sectional images was $1 \mu \mathrm{m}$ isotropic voxel side length with a grey scale resolution of 8 bit. The video of Angustopila huoyani sp. n. was created using a SkyScan 1172 scanner at RJL Micro \& Analytic GmbH, Karlsdorf-Neuthard, Germany. The scanner is equipped with a sealed micro focus x-ray source and a $11 \mathrm{Mpx}$ CCD detector. The specimen was scanned with $4 \mu \mathrm{m}$ voxel size in rotation steps of $0.6^{\circ}$ at $59 \mathrm{kV}$ tube voltage and $167 \mu \mathrm{A}$ tube current. Reconstruction with cross sectional images followed the same aforementioned, cone-beam reconstruction algorithm. Image resolution of the cross sectional images was $4 \mu \mathrm{m}$ isotropic voxel side length with a grey scale resolution of 8 bit. The animated video was generated using a direct volume rendering method implemented in the software CTvox.

Digital images: Angustopila huoyani sp. n. was photographed using a Kontron-ElectronikProgRes-3012 microscope camera (Jena, Germany) and a Leitz MZ12 stereomicroscope.

\section{Taxonomy}

Family Hypselostomatidae Zilch 1959

Genus Angustopila Jochum, Slapnik \& Páll-Gergely, gen. n. http://zoobank.org/2DD2207C-8C0E-46F0-A1D3-12F480F105BD http://species-id.net/wiki/Angustopila

Type species. Systenostoma tamlod Panha \& Burch 1999.

Diagnosis. Angustopila gen. n. is characterized by a very small, smooth, conical shell with regular, moderately increasing whorls. The body whorl sometimes extends beyond the penultimate whorl in profile. The sculpture of the protoconch is usually ornamented by spiral and radial lines resulting in a powdery, reticulated surface. The protoconch is slightly recessed into the second whorl. Aperture slightly or not adnate, with usually one or two denticles, peristome slightly reflexed. 
Etymology. The name derives from the combination of the Latin angustus (= narrow) and pila (= pillar, column). Gender: feminine.

Remarks. Angustopila gen. n. differs from Tonkinospira nom. n. (former Vietnamese Systenostoma) by smaller shell size, more elevated spire, slightly reflexed apertural rim and general dentition present within the aperture. Acinolaemus usually has more teeth and a turban-like shell. Krobylos species have angulated whorls, lack spiral lines on the shell and possess a relatively large, toothless, adnate aperture.

Distribution. The genus is known from Thailand and Malaysia. The Chinese Angustopila huoyani $\mathrm{sp} \mathrm{n}$. is located very distant, almost $1500 \mathrm{~km}$ from the northern Thai localities.

\section{Angustopila concava (Thompson \& Upatham, 1997)}

Systenostoma concava Thompson \& Upatham, 1997: Bulletin of the Florida Museum of Natural History, 39 (7): 231-232, Fig. 32-38. ["Thailand, Nakhon Ratchasima Province, limestone hill $3.4 \mathrm{~km}$ west of Ban $\mathrm{Mu} \mathrm{Si}, 380 \mathrm{~m}$ altitude $\left(14^{\circ} 32.0^{\prime} \mathrm{N}\right.$, $\left.\left.101^{\circ} 22.5^{\prime} \mathrm{E}\right)^{\prime \prime}\right]$

Systenostoma concava - Panha and Burch 2005: Malacological Review, 37/38: 118-119, Fig. 101.

\section{Angustopila elevata (Thompson \& Upatham, 1997)}

Systenostoma elevata Thompson \& Upatham, 1997: Bulletin of the Florida Museum of Natural History, 39 (7): 232-233, Fig. 39-43. ["Thailand, Chiang Mae Province, Doi Chiang Dao (Mountain), $7 \mathrm{~km}$ west of Chiang Dao; $600 \mathrm{~m}$ altitude $\left.\left(19^{\circ} 24.3^{\prime} \mathrm{N}, 98^{\circ} 54.2^{\prime} \mathrm{E}\right)^{\prime \prime}\right]$

Systenostoma elevata - Panha and Burch 2005: Malacological Review, 37/38: 120-121, Fig. 103.

\section{Angustopila huoyani Jochum, Slapnik \& Páll-Gergely, sp. n.} http://zoobank.org/2101F700-9723-422F-B70B-F8D0C2D20345 http://species-id.net/wiki/Angustopila_huoyani Figure 4-5, Video 1

Type material. China, Hunan, Longshan (龙山县), Huoyan (火焰), Feihu Dong (飞虎洞), (29 $12.53^{\prime} \mathrm{N}, 109^{\circ} 18.37^{\prime} \mathrm{E}, 550 \mathrm{~m}$ alt.), soil, leg. Verovnik, 13.04.1997, MCSMNH 50312/1 (holotype), MCSMNH 50312/2-9 (8 paratypes).

Diagnosis. A tiny, thin-shelled conical snail with very deep and narrow umbilicus, 5 shouldered whorls and two apertural denticles (parietal and palatal).

Description. Shell thin, greyish white, semi opaque; conical, widest at its base, with a homogeneous powdery superficial texture and regularly increasing, shouldered whorls 


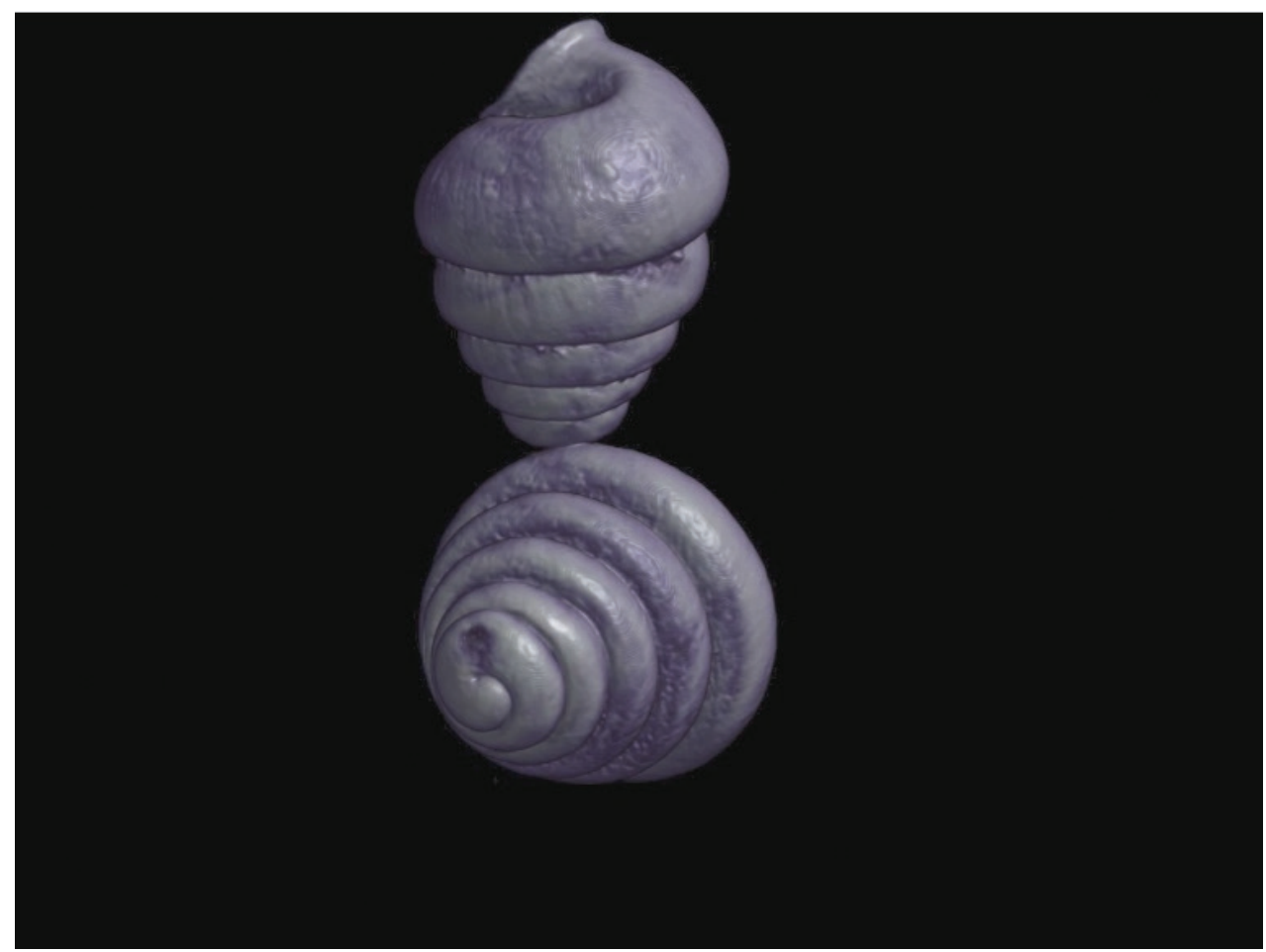

Video I. Micro-CT Video of Angustopila huoyani sp. n. Video: Markus Heneka.

Video available for download in full resolution from http://www.pensoft.net/J_FILES/1/articles/7488/ export.php_files/Jochum_Video_1.avi

separated by deep suture; smooth with no notable spiral or radial sculpture. It is characterized by very fine irregular axial lamellae and reticulating microgranules producing the powdery superficial texture; protoconch shows reticulating granules and recognisable radial lines only at the upper part of the first whorl; aperture semi-circular, slightly oblique from ventral view; peristome very slightly thickened and reflexed; parietal callus adnate (attached to the penultimate whorl); aperture with two well-developed but short denticles, one on the parietal and the other on the palatal side; umbilicus very deep and narrow.

Measurements. See Table 1.

Differential diagnosis. Tonkinospira defixa, T. pulverea, T. pauperrima and $T$. depressa are much larger than the new species, have reticulated sculpture and lack denticles in the aperture. Moreover, $T$. defixa has a more depressed spire, fewer whorls, wider umbilicus and slightly keeled body whorl; T. pulverea has fewer whorls, a comparatively larger aperture, somewhat keeled, wider body whorl and its umbilicus is partly closed by the apertural margin; T. pauperrima shows increased bulging in whorl configuration; $T$. depressa has a lower spire, slightly keeled body whorl and a large aperture without denticles. Hypselostoma (?) edentata also lacks denticles in the aperture and possesses a very wide, laterally compressed body whorl. A. tamlod, the most similar species, is slightly smaller, has fewer whorls, wider umbilicus and obvious spiral 
Table I. Shell measurements (mm) for Angustopila huoyani sp. n. from the type locality. SH - shell height, SW - shell width, AH - aperture height, AW - aperture width, SW/SH×100 - shell width shared with shell height and multiplied 100, AW/AH $\times 100$ - aperture width shared with aperture height and multiplied 100).

\begin{tabular}{c|c|c|c|c|c|c}
\hline SH & SW & AH & AW & SW/SH $\times \mathbf{1 0 0}$ & AW/AH $\times \mathbf{1 0 0}$ & specimen \\
\hline 1.09 & 0.87 & 0.33 & 0.43 & 80 & 133.33 & Holotype \\
\hline 1.13 & 0.91 & 0.41 & 0.43 & 80.77 & 105.26 & Paratype \\
\hline 1.09 & 0.89 & 0.35 & 0.41 & 82 & 118.75 & Paratype \\
\hline 1.13 & 0.91 & 0.39 & 0.41 & 80.77 & 105.55 & Paratype \\
\hline 1.20 & 0.96 & 0.43 & 0.43 & 80 & 100 & Paratype \\
\hline 1.22 & 41641 & 0.39 & 0.46 & 83.93 & 116.66 & Paratype \\
\hline 1.09 & 0.89 & 0.35 & 0.39 & 82 & 112.5 & Paratype \\
\hline 1.09 & 0.91 & 0.33 & 0.39 & 84 & 120 & Paratype \\
\hline 1.30 & 0.89 & 0.39 & 0.37 & 68.33 & 94.44 & Paratype \\
\hline
\end{tabular}

Table 2. Average. minimum value (min). maximum value (max). variance of values (var) and standard deviation of a set of values (stdev) for Angustopila huoyani sp. n. $\mathrm{N}=30$.

\begin{tabular}{c|c|c|c|c|c|c}
\hline & SH & SW & AH & AW & SW/SH×100 & AW/AH×100 \\
\hline Average & 1.17 & 0.94 & 0.37 & 0.43 & 80.09 & 114.20 \\
\hline Min & 1.04 & 0.85 & 0.33 & 0.37 & 68.33 & 94.44 \\
\hline Max & 1.30 & 1.04 & 0.43 & 0.46 & 87.50 & 133.33 \\
\hline Var & 0.0058 & 0.0031 & 0.0008 & 0.0007 & 15.4080 & 79.0895 \\
\hline stdev & 0.0765 & 0.0560 & 0.0288 & 0.0288 & 3.9253 & 8.8932 \\
\hline
\end{tabular}

striation on the teleoconch. A. concava has a much wider body whorl than that of $A$. huoyani, has weaker apertural denticles and prominent spiral sculpture. A. elevata has no denticles in the aperture and possesses a wider umbilicus and spirally striated shell. $A$. neglecta (see also notes under that species) has a wider umbilicus and more rapidly growing whorls, resulting in a comparatively wider body whorl than in the new species. A. neglecta also has spiral lines on the shell and its sinulus is wider. Shell characters and ecological information of all Angustopila species are presented in Table 3.

Etymology. The new species is named after the Gorges of Huoyan, where the type locality is located.

Distribution. The new species is known from the type locality only.

Ecology. The new species is known only from the Feihu Dong ("Cave of the Wind Tiger"). A. huoyani were culled from samples of rocky-loamy substrate collected in the entrance corridor of the cave. It is highly likely that the distribution of $A$. huoyani sp. $\mathrm{n}$. is restricted to this cave only.

Conservational status. Our knowledge of the biogeography of the genus is very limited. However, we assume that most Angustopila, especially the cave-dwelling species, are narrow-range endemics. Since extreme endemism always makes species vulnerable to human encroachment, this species warrants conservation priority. Currently, no direct threats are known. 
Table 3. The most important morphological traits and ecological information for Angustopila huoyani sp. n. and its congeners extracted from the literature.

\begin{tabular}{|c|c|c|c|c|c|}
\hline & concava & elevata & buoyani sp. n. & neglecta & tamlod \\
\hline Shell colour & greyish white & light gray & greyish white & white & white \\
\hline $\begin{array}{l}\text { Teleoconch } \\
\text { sculpture }\end{array}$ & $\begin{array}{l}\text { spiral threads; } \\
\text { weak growth } \\
\text { wrinkles }\end{array}$ & $\begin{array}{l}\text { spiral threads; } \\
\text { weak growth } \\
\text { wrinkles }\end{array}$ & $\begin{array}{l}\text { very fine irregular } \\
\text { axial lamellae, } \\
\text { reticulating } \\
\text { microgranules }\end{array}$ & $\begin{array}{l}\text { spiral threads; } \\
\text { growth wrinkles }\end{array}$ & spiral threads \\
\hline $\begin{array}{l}\text { Protoconch } \\
\text { sculpture }\end{array}$ & spiral/ reticulated & $\begin{array}{l}\text { reticulating } \\
\text { granules }\end{array}$ & $\begin{array}{l}\text { reticulating } \\
\text { granules }\end{array}$ & not described & not decribed \\
\hline $\begin{array}{c}\text { Aperture shape/ } \\
\text { peristome }\end{array}$ & $\begin{array}{c}\text { kidney-shaped, } \\
\text { oblique }\end{array}$ & ovate, oblique & $\begin{array}{c}\text { semi-circular, } \\
\text { oblique }\end{array}$ & ovate & semi-circular \\
\hline Aperture dentition & $\begin{array}{l}\text { angular, upper } \\
\text { palatal, parietal }\end{array}$ & dentition lacking & parietal, palatal & $\begin{array}{c}\text { angular, upper } \\
\text { palatal, weak } \\
\text { basal }\end{array}$ & parietal, palatal \\
\hline Umbilicus & narrow & narrow & very narrow & relatively wide & very narrow \\
\hline Whorl number & $4.6-5.3$ & $4.2-4.3$ & 5.3 & 4.5 & 4.75 \\
\hline Shell height (mm) & $1.02-1.21$ & $0.92-0.99$ & $1.04-1.3$ & $1.2-1.8$ & $0.9-1.0$ \\
\hline Ecology & $\begin{array}{c}\text { leaf litter } \& \\
\text { limestone talus }\end{array}$ & $\begin{array}{c}\text { leaf litter } \& \\
\text { limestone talus }\end{array}$ & cave & cave (?) & cave \\
\hline
\end{tabular}

\section{Angustopila neglecta (van Benthem-Jutting, 1961)}

Hypselostoma laidlawi-Benthem Jutting ? 1949 : Bulletin of the Raffles Museum, 21: 19, Fig. 9.

Paraboysidia neglecta van Benthem Jutting 1961: Bulletin of the Raffles Museum, 26:

36, Plate 8, Fig. 2a. ["Biserat Caves, State of Jalor" and "Gua Che Yatin, Ulu

Tembeling, Pahang"]

"Hypselostoma laidlawi" (referring to the figure in Benthem-Jutting (1949) as probably

Systenostoma species) - Panha and Burch 1999: Walkerana, 10 (24): 125.

Remarks. Although the specimen on Benthem Jutting's (1949) figure is similar, it probably is not conspecific to her other figure (Benthem Jutting 1961). See detailed explanation in Panha and Burch (1999).

\section{Angustopila tamlod (Panha \& Burch, 1999)}

Systenostoma tamlod Panha \& Burch, 1999: Walkerana 10 (24): 118-121, Fig. 3. ["Lod Cave, Pang Ma Pa District, Mae Hong Son Province, 19²9'36"N, 98¹7'18"E and $10^{\circ} 34^{\prime} 03^{\prime \prime} \mathrm{N}, 98^{\circ} 16^{\prime} 41^{\prime \prime E}, 800$ meters elevation (CUIZM, Ver 025), Thailand. All specimens were collected inside the cave, almost two kilometres from the entrance."] 


\section{Genus Hypselostoma Benson 1856}

http://species-id.net/wiki/Hypselostoma

Hypselostoma Benson 1856b, The Annals and Magazine of Natural History, ser. 2, no. 17: 342. (nom. n. for Tanystoma Benson 1856a, non Latreille 1829).

Type species. Tanystoma tuberiferum Benson 1856 by monotypy.

Remarks. Systenostoma edentata Panha \& Burch, 1999 differs from all former, Thai Systenostoma species by the relatively large, toothless, adnate aperture. It is probably a toothless member of a hypselostomatid genus other than former Systenostoma. Here, S. edentata is placed within the genus Hypselostoma because its similarity with H. panhai Burch \& Tongkerd 2002. H. panhai is not a typical member of the genus Hypselostoma in terms of shell characters, but was placed into this genus based on molecular data of Tongkerd et al. (2004).

\section{Hypselostoma (?) edentata (Panha \& Burch, 1999)}

Systenostoma edentatum Panha \& Burch, 1999: Walkerana, 10 (24): 121-124, Fig. 4 a-d. [“Tamphatai National Park, Phrae Province, 18³6"20'N, 9953"49'E, 650 meters elevation (CUIZM, Ver 022), Thailand"]

Systenostoma edentata - Panha and Burch 2005: Malacological Review, 37/38: 119120, Fig. 102.

\section{Genus Tonkinospira Jochum, Slapnik \& Páll-Gergely, nom. n.}

Systenostoma Bavay \& Dautzenberg, 1908: Journal de Conchyliologie, 56: 243.

Systenostoma - Bavay and Dautzenberg 1909: Journal de Conchyliologie, 57: 196. (diagnosis).

Remarks. The name Systenostoma Bavay \& Dautzenberg, 1908 is preoccupied (non Systenostoma Marsson 1887, Bryozoa). Therefore, Tonkinospira Jochum, Slapnik \& Páll-Gergely nom. $\mathrm{n}$. is proposed as replacement.

Type species. Helix (Systenostoma) pauperrima Bavay \& Dautzenberg, 1908 by subsequent designation (Pilsbry 1917).

Diagnosis. A genus of small, conical or depressed-conical species with regularly growing, rounded or angulated whorls. The sculpture is characterized by spiral lines on both the protoconch and the teleoconch, decussated by irregular radial lines resulting in a reticulated surface structure. The aperture is toothless, adnate or slightly adnate and shows a sharp peristome.

Etymology. The new name is established by the fusion of Tonkin (northern Vietnam, the area of distribution) and the Latin spira (a coil, twist). Gender: feminine. 
Remarks. Tonkinospira differs from Krobylos by the increased degree of angulation of the whorls and the lack of spiral lines on the teleoconch. For differences with Angustopila gen. n., see above.

The systematic position of the genus is questionable. It most probably belongs to the family Hypselostomatidae, but its relationship with other families such as Helicodiscidae (see Schileyko 1998) or Valloniidae (see Schileyko 2011) cannot be excluded.

Distribution. So far, the genus is reported from Northern Vietnam only.

\section{Tonkinospira defixa (Bavay \& Dautzenberg, 1912)}

http://species-id.net/wiki/Tonkinospira_defixa

Figure 1

Systenostoma defixa Bavay \& Dautzenberg 1912: Journal de Conchyliologie, 60: 2223, Plate 1, Fig. 18-19. ["Île de la Table, baie d'Along"].

Systenostoma defixa - Pilsbry 1917: Manual of Conchology...: 226, Plate 38, Figs $15-16$.

Material examined. Systenostoma defixa (Bavay \& Dautzenberg, 1912) (2 specimens), RBINS Dautzenberg Collection reg. nr. IG 10591 (tray 844), probably syntypes.

Remarks. The whole shell, including the protoconch, is covered with regular, very fine spiral threads. The spiral lines are decussated with rather irregular radial lines, creating a reticulated surface.

\section{Tonkinospira depressa (Jaeckel 1950)}

Systenostoma depressa Jaeckel 1950: Archiv für Molluskenkunde, 79: 15-16, Plate 1,

Fig. 1. [from river debris, no type locality specified].

\section{Tonkinospira pauperrima (Bavay \& Dautzenberg, 1908)}

http://species-id.net/wiki/Tonkinospira_pauperrima

Figure 2

Helix (Systenostoma) pauperrima Bavay \& Dautzenberg 1908: Journal de Conchyliologie, 56: 243-244. ["Phu-Quoc-Oaï"].

Helix (Systenostoma) pauperrima - Bavay and Dautzenberg 1909: Journal de Conchyliologie, 57: 195-196, Plate 8, Fig. 4-6. [“Trouvé à Phu-Quoc-Oaï, parmi les détritus coquilliers"]

Systenostoma pauperrima - Pilsbry 1917: Manual of Conchology...: 225-226, Plate 38, Figs 3-5.

Systenostoma pauperrima - Schileyko Ruthenica 1998: Supplement 2(2): 165, Fig. 202. 

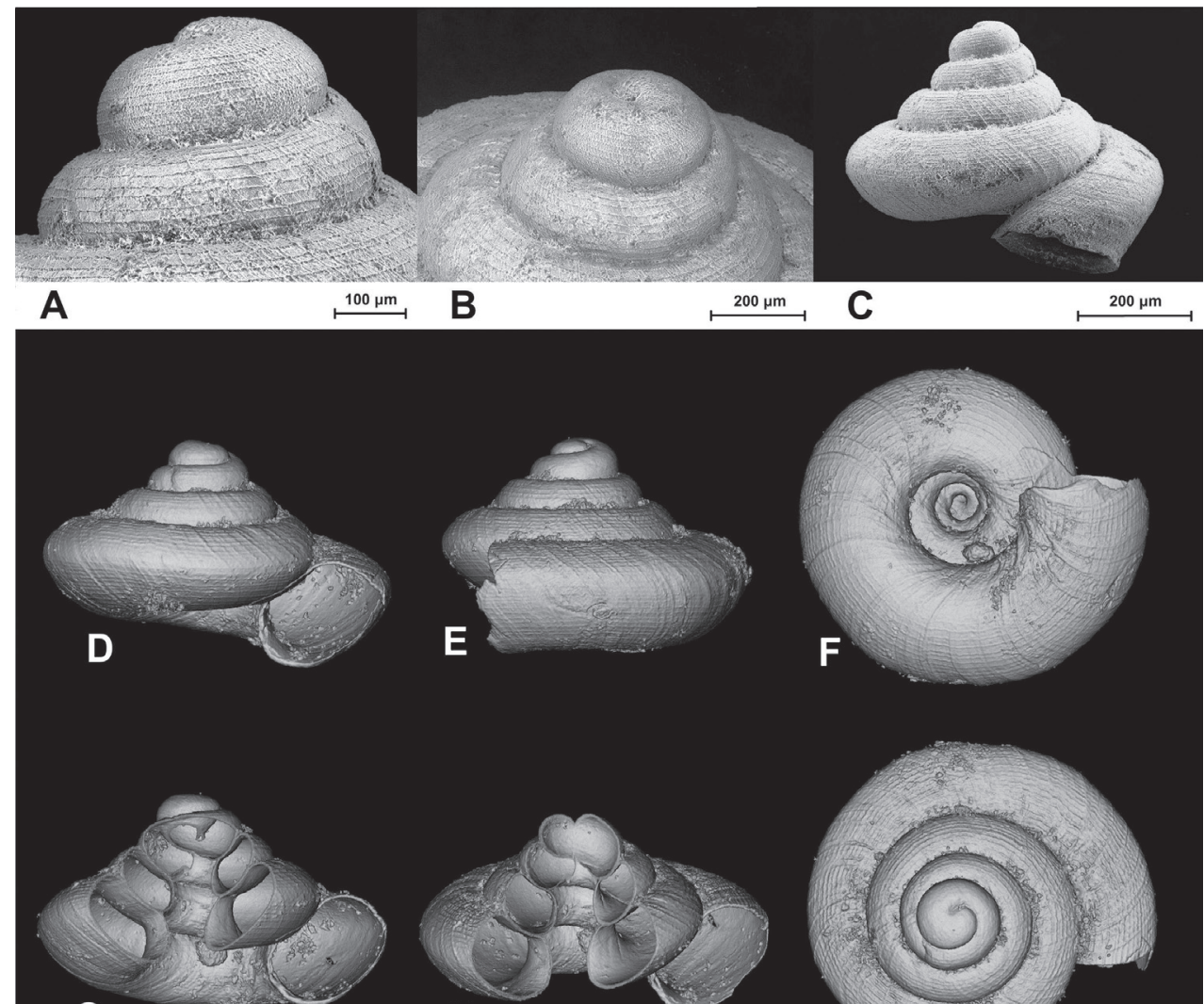

G
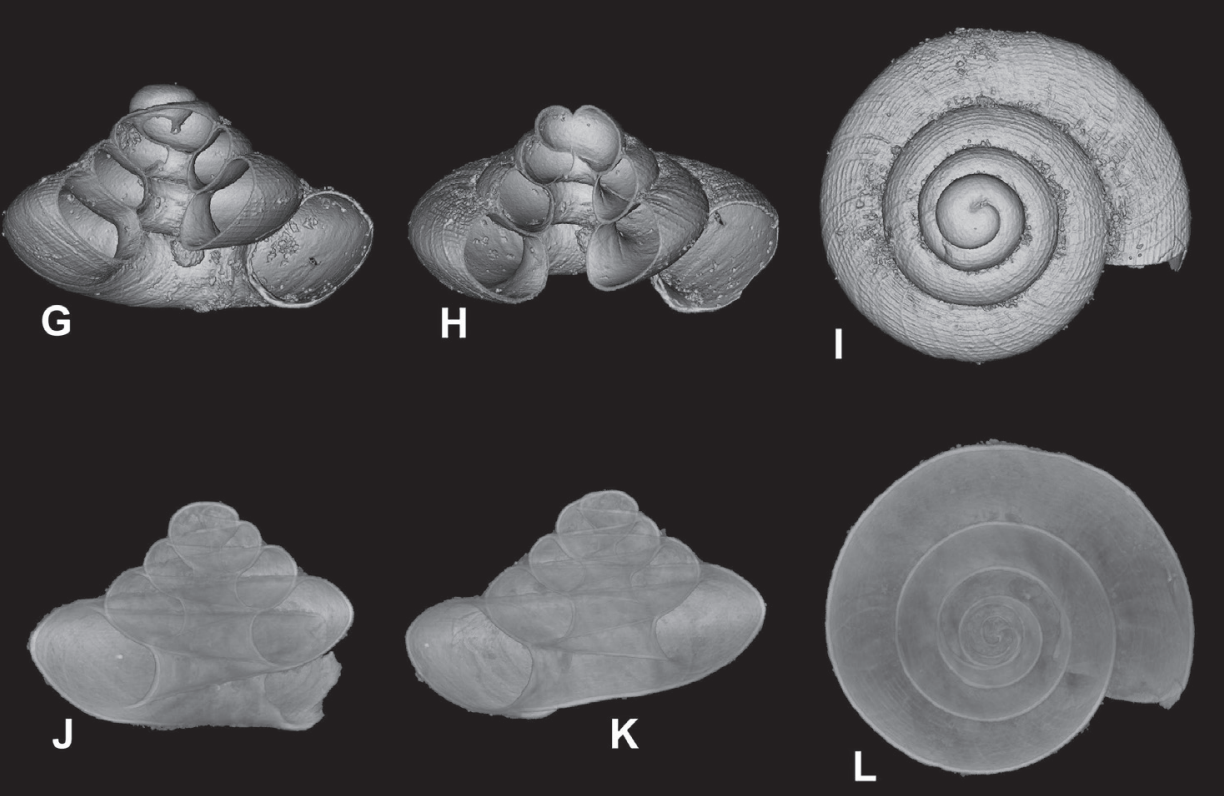

Figure I. SEM (A-C) and Nano-CT Volume Compositing 3D (D-I) and Nano-CT Summed Voxel Projection images (J-L) of Tonkinospira defixa (Bavay \& Dautzenberg, 1912). RBINS Dautzenberg Collection reg. nr. IG 10591 (tray 844). Type locality material. Photos: SEM: Suzanne Leidenroth (SMNS). Nano-CT: Gunhild Martels.

Material examined. Helix (Systenostoma) pauperrima (Bavay \& Dautzenberg, 1908) (1 specimen). RBINS Dautzenberg Collection reg. nr. IG 10591 (tray 844), probably syntype. 

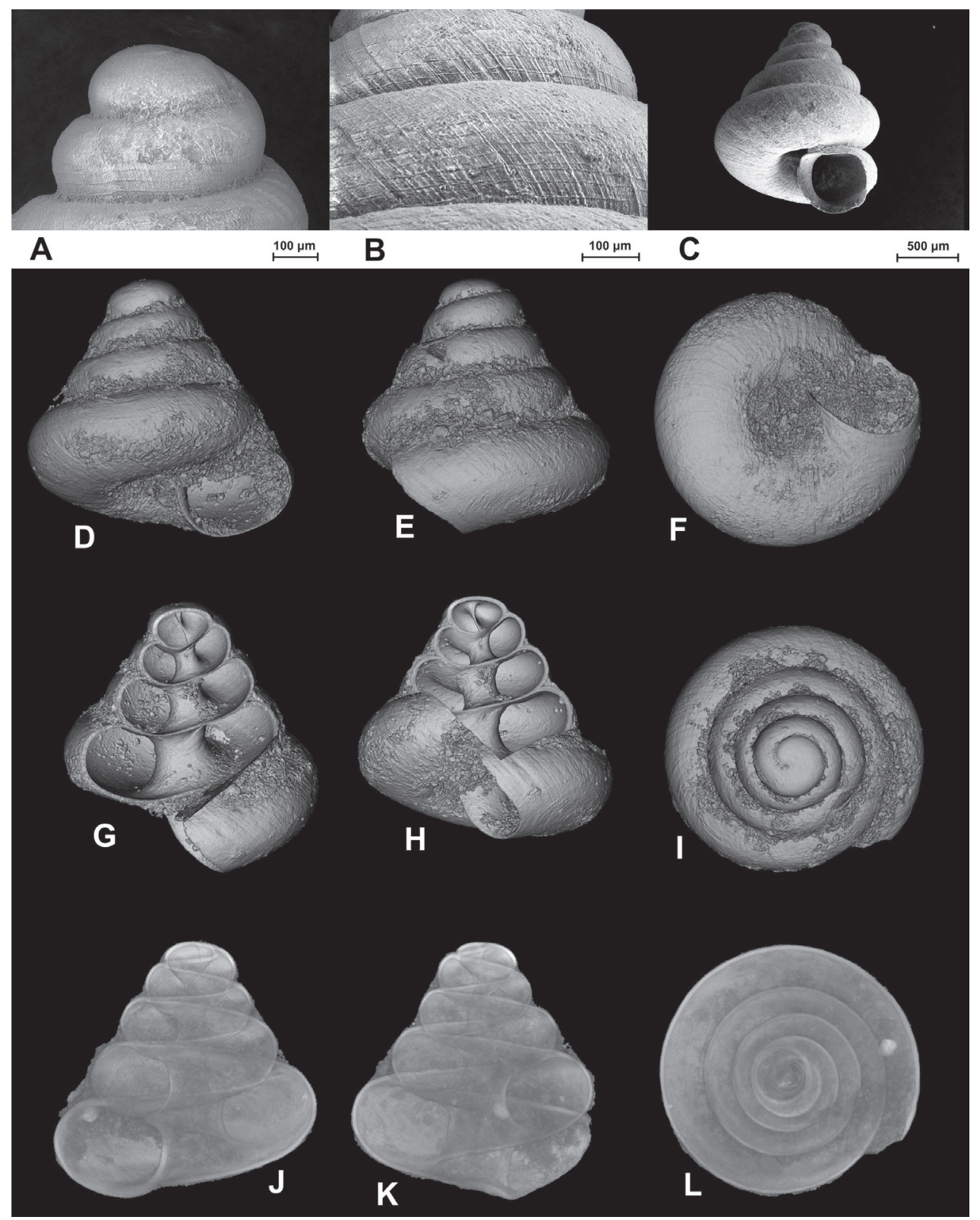

Figure 2. SEM (A-C) and Nano-CT Volume Compositing 3D (D-I) and Nano-CT Summed Voxel Projection images (J-L) of Tonkinospira pauperrima (Bavay \& Dautzenberg, 1908). RBINS Dautzenberg Collection reg. nr. IG 10591 (tray 844). Type locality material. Photos: SEM: Suzanne Leidenroth (SMNS). Nano-CT: Gunhild Martels. 

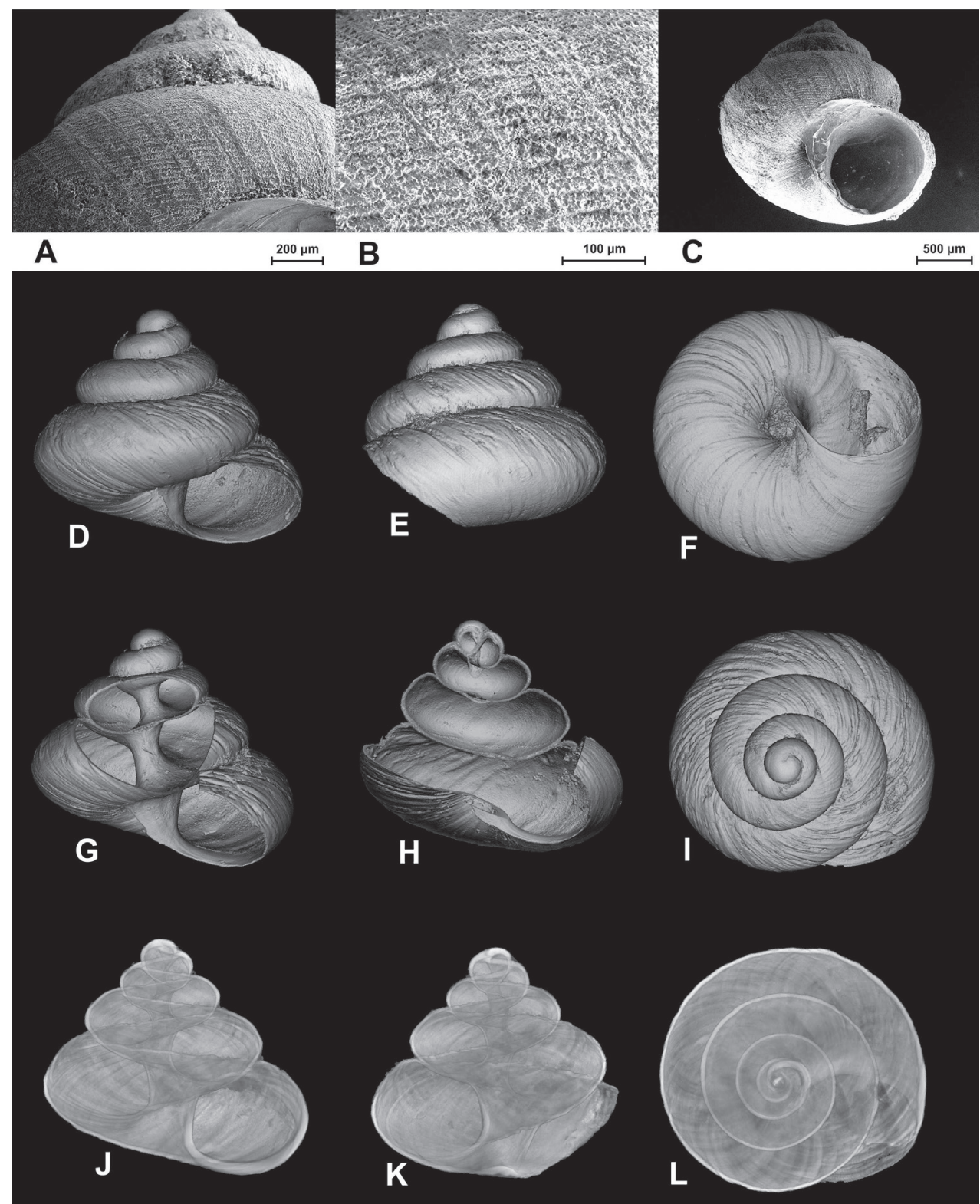

Figure 3. SEM (A-C) and Nano-CT Volume Compositing 3D (D-I) and Nano-CT Summed Voxel Projection images (J-L) of Tonkinospira pulverea (Bavay \& Dautzenberg, 1908). RBINS Dautzenberg Collection reg. nr. IG 10591 (tray 844). Type locality material. Photos: SEM: Suzanne Leidenroth (SMNS). Nano-CT: Gunhild Martels. 


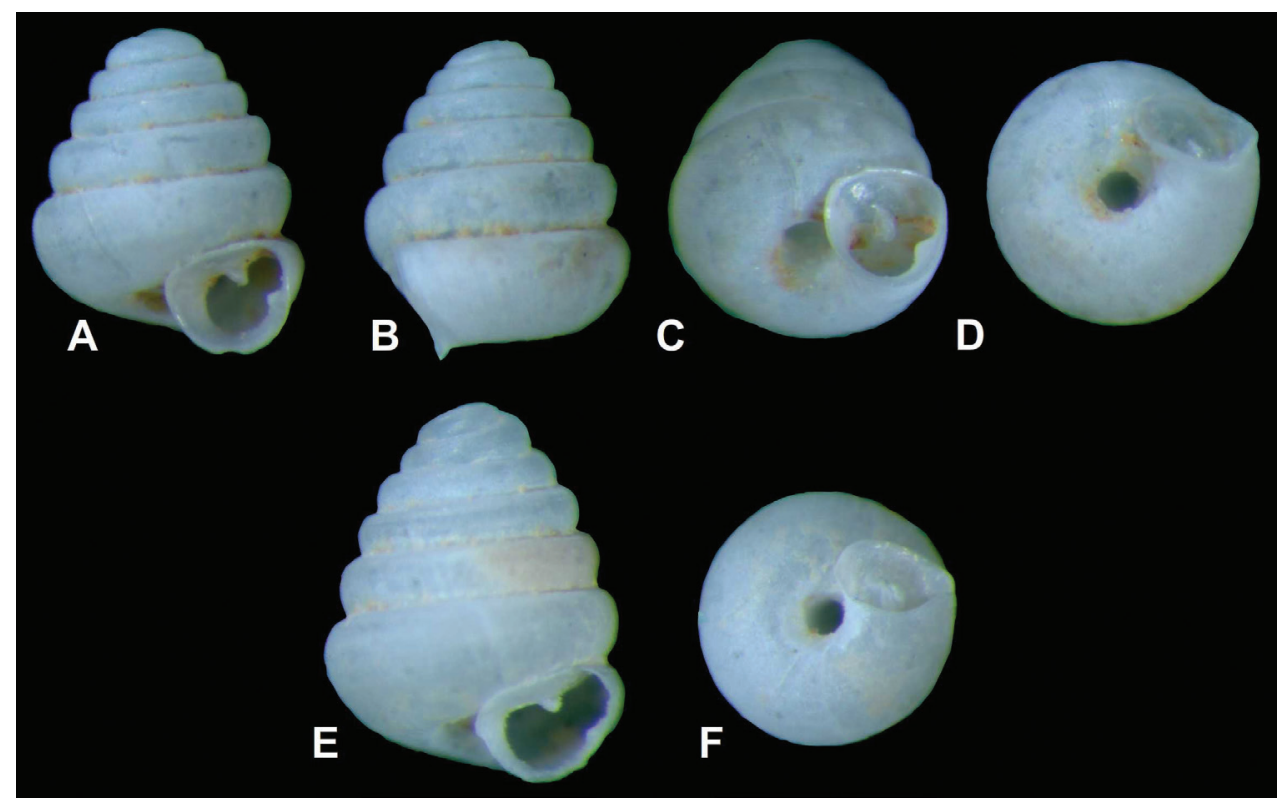

Figure 4. Holotype (A-D) and paratype (E-F) specimens of Angustopila huoyani sp. n. China, Hunan (湖南省), Xiangxi (湘西土家族苗族自治州), Longshan (龙山县), Huoyan (火焰), Feihu Dong (飞虎洞), (ca. $\left.29^{\circ} 12.53^{\prime} \mathrm{N}, 109^{\circ} 18.37^{\prime} \mathrm{E}\right)$, soil, leg. Verovnik, 13.04.1997. Photos: Sigrid Hof (SMF).

Remarks. The whole shell, including the protoconch is covered with regular, extremely fine spiral threads. The number of threads increases from the apex towards the aperture. The spiral lines are decussated with irregular radial lines, resulting in in a reticulated surface.

\section{Tonkinospira pulverea (Bavay \& Dautzenberg, 1908)}

http://species-id.net/wiki/Tonkinospira_pulverea

Figure 3

Helix (Systenostoma) pulverea Bavay \& Dautzenberg, 1908: Journal de Conchyliologie, 56: 243. ["Phu-Quoc-Oai"].

Helix (Systenostoma) pulverea - Bavay and Dautzenberg 1909: Journal de Conchyliologie, 57: 194-195, Plate 8, Fig. 7-9. ["Vit sur les rochers de Phu-Quoc-Oaii"] Systenostoma pulverea - Pilsbry 1917: Manual of Conchology...: 225, Plate 38, Figs 10-12.

Material examined. Helix (Systenostoma) pulverea Bavay \& Dautzenberg, 1908 (1 specimen), RBINS Dautzenberg Collection reg. nr. IG 10591 (tray 844), probably syntype.

Remarks. The teleoconch shows rather regular, very fine spiral threads. These spiral lines are more numerous than in the other two examined species. The spiral lines are decussated. Irregular, impressed varices occur at intervals across the whorls. At higher magnification, the shell shows a highly flocculent texture. 


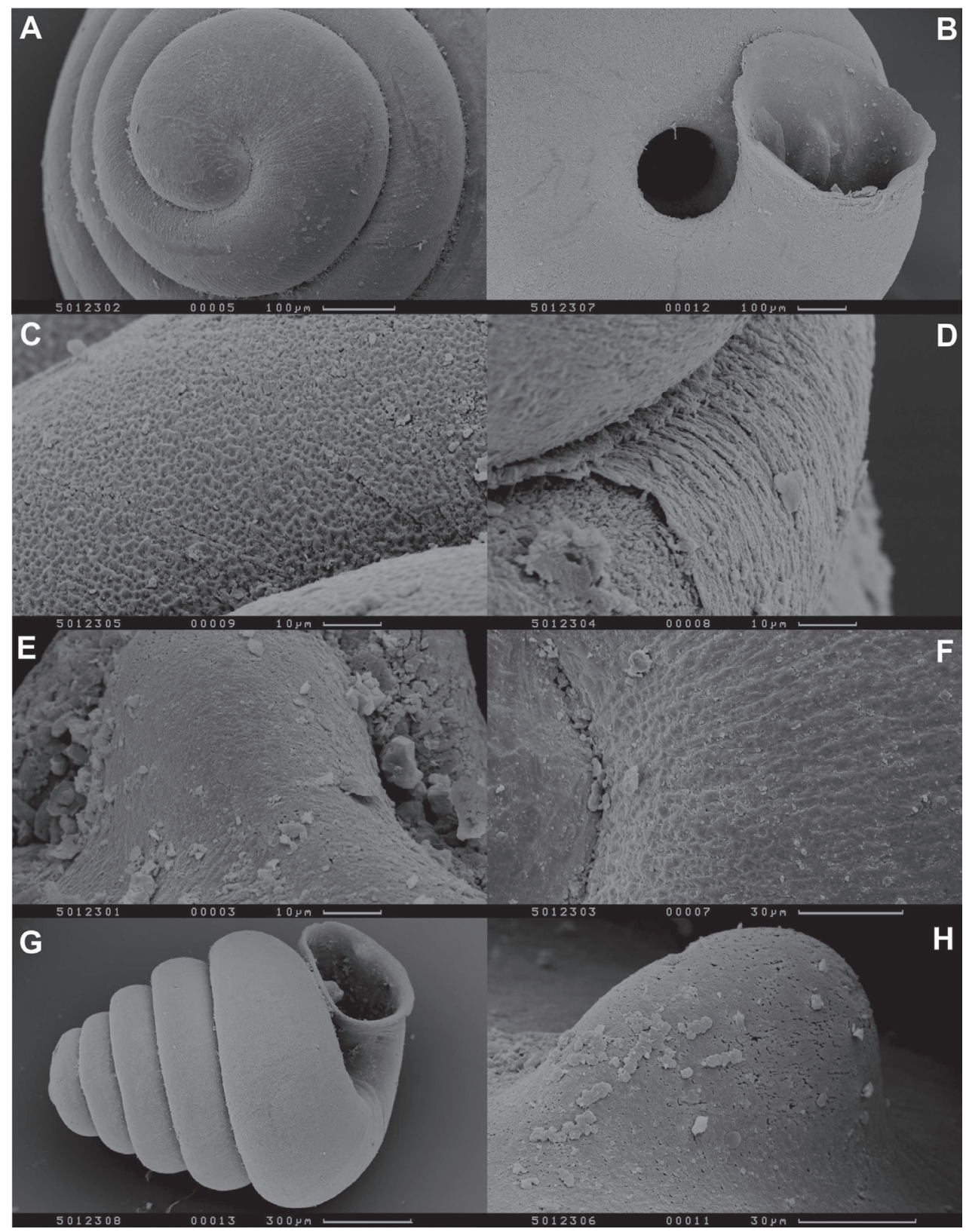

Figure 5. SEM images of Angustopila huoyani sp. n. paratype. Same data as in Fig. 4. A protoconch $\mathbf{B}$ umbilicus and adnate aperture $\mathbf{C}$ reticulating microgranules on whorls $\mathbf{D}$ fine axial lamellae $\mathbf{E}$ palatal denticle $\mathbf{F}$ reticulation on protoconch $\mathbf{G}$ shell profile $\mathbf{H}$ parietal callus. Photos: Yaron Malkowsky (SMF). 


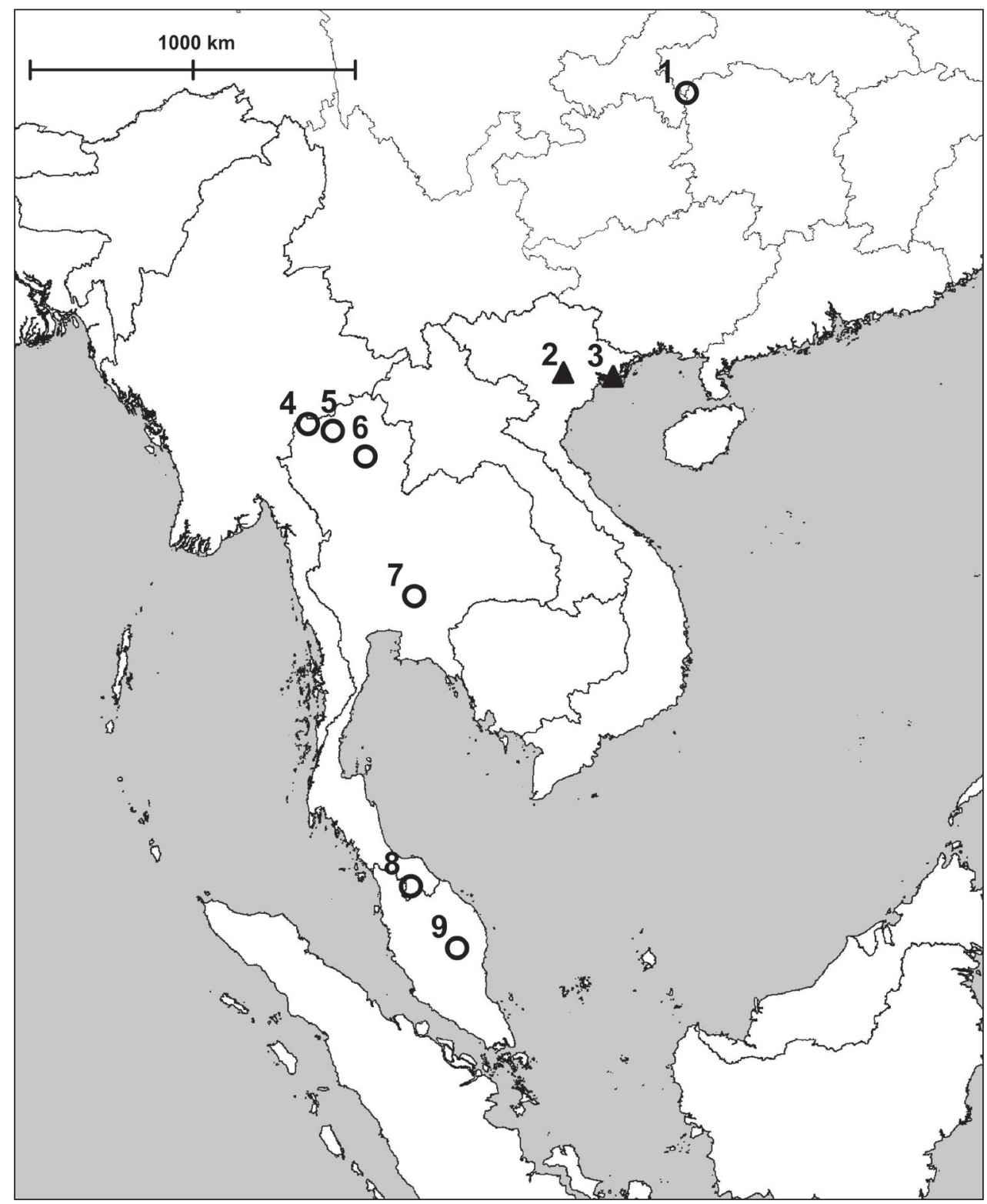

Figure 6. Map showing the localities of Angustopila gen. n. (empty circle) Tonkinospira nom. n. (filled triangle) and species. I Angustopila huoyani sp. n. 2 Tonkinospira pauperrima (Bavay \& Dautzenberg, 1908) and T. pulverea (Bavay \& Dautzenberg, 1908) 3 T. defixa (Bavay \& Dautzenberg, 1912) 4 A. tamlod (Panha \& Burch, 1999) 5 A. elevata (Thompson \& Upatham, 1997) 6 A. edentata (Panha \& Burch, 1999) 7 A. concava (Thompson \& Upatham, 1997) 8, 9 A. neglecta (van Benthem-Jutting, 1961). 


\section{Acknowledgements}

We are very grateful of Nguyen Duc Anh (Hanoi, Vietnam) for his help in clarifying old Vietnamese locality names and to Zoltán Fehér (HNHM) for his assistance in constructing the map. We thank Rose Sablon and Yves Samyn (RBINS) for providing valuable insights and collection material. Our gratitude also goes to Tomi Trilar (SMNH) for providing material of the new species. We additionally thank Ronald Janssen and Ira Richling (SMNS) for their kind help and use of their SEM facilities as well as Suzanne Leidenroth (SMNS) and Yaron Malkowsky (SMF) for their expert help with the SEM. Boris Sket provided valuable ecological data. Special gratitude also goes to Sigrid Hof (SMF) for her photographic patience imaging the minute A. huoyani. We are grateful to the anonymous reviewer for reviewing the manuscript. Lastly, we are indebted to The Biodiversity Heritage Library for providing access to the multitude of rare literature consulted for this work (www.biodiversitylibrary.org).

\section{References}

Ancey CF (1881) Descriptions de Mollusques Terrestres Nouveaux. Le Naturaliste Vol 1, no. 47: 373-374. http://biodiversitylibrary.org/item/105816\#page/373/mode/1up

Bavay A, Dautzenberg Ph (1908) Molluscorum Terrestrium Tonkinorum Diagnoses. Journal de Conchyliologie 56: 229-251. http://biodiversitylibrary.org/item/55061\#page/269/mode/1 up Bavay A, Dautzenberg Ph (1909) Description de Coquilles Nouvelles de l'Indo-Chine. Journal de Conchyliologie 57: 163-206.

Bavay A, Dautzenberg Ph (1912) Description de Coquilles Nouvelles de l'Indo-Chine. Journal de Conchyliologie 60: 1-54. http://biodiversitylibrary.org/item/55204\#page/15/mode/1up

Benthem Jutting WSS van (1949) The Malayan species of Boysidia, Paraboysidia, Hypselostoma, and Gyliotrachela (Gastropoda, Pulmonata, Vertiginidae) with a catalogue of all the species hitherto described. Bulletin of the Raffles Museum 21: 5-49.

Benthem Jutting WSS van (1961) Additional new Species and new Localities of the Family Vertiginidae and the Genera Oophana and Opisthostoma from Malaya. Bulletin of the Raffles Museum 26: 34-48.

Benson WH (1856a) Description of Tanystoma tuberiferum, a Burmese form related to the genus Anostoma of Lamarck. The Annals and Magazine of Natural History ser. 2, no. 17: 129-131. http://biodiversitylibrary.org/item/19391\#page/153/mode/1up

Benson WH (1856b) Remarks on the genera Tanystoma, Nematura, and Anaulus. The Annals and Magazine of Natural History ser. 2, no. 17: 342-343. http://biodiversitylibrary.org/ item/19391\#page/379/mode/1up

Jaeckel SH (1950) Die Mollusken eines tropischen Flußgenistes aus Tonkin. Archiv für Molluskenkunde 79: 15-20. 
Langheinrich AC, Yeniguen M, Ostendorf A, Marhoffer S, Dierkes C, Gerlach von S, Nedelmann M, Kampschulte M, Bachmann G, Stolz E, Geriets T (2010) In vitro evaluation of the sinus sagittalis superior thrombosis model in the rat using $3 \mathrm{D}$ micro- and nanocomputed tomography. Neuroradiology 52: 815-821. doi: 10.1007/s00234-009-0617-5

Marsson TF (1887) Die Bryozoen der weissen Schreibkreide der Insel Rügen. Paläontologische Abhandlungen 4: 1-122.

Panha S, Burch JB (1999) New taxa of Pupillidae (Pulmonata: Stylommatophora) from Thailand. Walkerana 10 (24): 113-134. http://molluskconservation.org/WALKERANA/ Vol10/walkerana\%20vol10\%20no24\%201-134.PDF

Panha S, Burch JB (2005) An introduction to the microsnails of Thailand. Malacological Review 37/38: $1-155$.

Pilsbry HA (1916-1918) Manual of Conchology, Second Series: Pulmonata, Vol. 24, Pupillidae (Gastrocoptinae). Conchological Department, Academy of Natural Sciences of Philadelphia, Philadelphia, 380 pp, plates 1-50. http://biodiversitylibrary.org/item/16727\#page/5/ mode/1up

Schileyko AA (1998) Treatise on Recent terrestrial pulmonate molluscs. Part 2. Gastrocoptidea, Hypselostomatidae, Vertiginidae, Truncatellinidae, Pachynodidae, Enidae, Sagdidae. Ruthenica Supplement 2(2): 129-261.

Schileyko AA (2011) Check-list of land pulmonate molluscs of Vietnam (Gastropoda: Stylommatophora). Ruthenica 21(1): 1-68. http://www.ruthenica.com/documents/vol21_Schileyko_1-68.pdf

Tomlin JR le B (1929-1931) Some preoccupied generic names. Proceedings of the Malacological Society of London 18: 255-256, 258; 19: 174-175.

Thompson FG, Upatham S (1997) Vertiginid land snails from Thailand (Gastropoda, Pulmonata, Pupilloidea). Bulletin of the Florida Museum of Natural History 39(7): 221-245. http://ufdc.ufl.edu/UF00095785/

Tongkerd P, Lee T, Panha S, Burch JB, O’ Foighil D (2004) Molecular phylogeny of certain Thai gastrocoptine micro land snails (Stylommatophora: Pupillidae) inferred from mitochondrial and nuclear ribosomal DNA sequences. Journal of Molluscan Studies 70: 139-147. doi: 10.1093/mollus/70.2.139, http://mollus.oxfordjournals.org/content/70/2/139.full. pdf + html 